\title{
Phytoplankton are more tolerant to UV than bacteria and viruses in the northern South China Sea
}

\author{
Xiangcheng Yuan ${ }^{1,2}$, Kedong Yin ${ }^{3,4, *}$, Paul J. Harrison ${ }^{2}$, Jiangtao Zhang ${ }^{1}$ \\ ${ }^{1}$ State Key Laboratory of Tropical Oceanography, South China Sea Institute of Oceanology, Chinese Academy of Sciences, \\ Guangzhou 510301, PR China \\ ${ }^{2}$ Division of Environment, Hong Kong University of Science and Technology, Clear Water Bay, Kowloon, Hong Kong SAR \\ ${ }^{3}$ School of Marine Sciences, Zhong Shan (Sun Yat-Sen) University, Guangzhou 510275, PR China \\ ${ }^{4}$ Environmental Futures Centre, Griffith University (Nathan Campus), Brisbane, Queensland 4111, Australia
}

\begin{abstract}
In late summer of 2005, the effects of ultraviolet radiation (UVR) on primary production (PP), bacterial production (BP) and viral decay rates (VDR) were investigated along a salinity gradient in the northern South China Sea. The freshwater input increased the UVA diffuse attenuation coefficient (up to $2.7 \mathrm{~m}^{-1}$ ) near the Pearl River estuary and consequently influenced the UVR inhibitory effects, as VDR was significantly correlated with the UVA diffuse attenuation coefficient. UVR inhibition of PP was significantly higher in upwelled waters than downwelled waters, suggesting that the vertical mixing (i.e. upwelling and downwelling) was an important factor regulating microbial sensitivity to UVR. UVR inhibited PP and BP by $\sim 15$ and $25 \%$, respectively, and the UVR inhibition of BP was significantly higher than that of PP in most of the samples; hence there was a competitive advantage for phytoplankton over bacteria under the relatively high UVR exposure. UVR increased VDR by $~ 30 \%$, which decreased bacterial mortality by 0.12 to $0.3 \% \mathrm{~h}^{-1}$ and mitigated the inhibitory effects of UVR on bacteria. In general, phytoplankton were more tolerant than bacteria and viruses to UVR in the sub-tropical northern South China Sea.
\end{abstract}

KEY WORDS: Bacterial production · Primary production · Viral decay · Ultraviolet radiation • South China Sea

\section{INTRODUCTION}

Solar ultraviolet radiation (UVR, 280 to $400 \mathrm{~nm}$ ) is an important environmental factor regulating microbial activities such as phytoplankton (Hamre et al. 2008), bacterial production (Ogbebo \& Ochs 2008) and viral growth (Fuhrman \& Noble 1995). UVR can affect microbial organisms by damaging DNA (Buma et al. 2001), reducing or increasing the availability of dissolved organic matter (DOM) and nutrients (Ziegler \& Benner 2000), and inhibiting larger grazers (Medina-Sánchez et al. 2006).
Effects of UVR on phytoplankton have received more attention earlier than those on viruses and bacteria. A large number of recent studies indicate that phytoplankton communities were inhibited by solar UVR from polar to tropical waters (Estevez et al. 2001, Gao et al. 2007). Aquatic bacteria have been shown to be sensitive to sunlight radiation, especially to the shortest-wavelength fraction of UV radiation (Müller-Niklas et al. 1995, Joux et al. 1999, Winter et al. 2001). Bacteria have previously been assumed to be more susceptible to UVR stress than larger eukaryotic organisms (e.g. phytoplankton) because 
of their smaller size and lack of UVR-screening pigments (Garcia-Pichel 1994, Lindell et al. 1995, Jeffrey et al. 2000). Bacteria are considered to be too small to develop effixcient photoprotection against UVR (Garcia-Pichel 1994) because their genetic material comprises a significant portion of their cellular volume (Jeffrey et al. 2000). Therefore, bacteria are probably among the most susceptible group to photodamage within the plankton (Garcia-Pichel 1994, Conan et al. 2008). On the other hand, opposite results showed that UVB indirectly stimulates bacterial growth by photodegrading DOM to low molecular weight compounds (Lindell et al. 1995, Obernosterer et al. 1999). In contrast to those studies on bacteria, previous studies on viruses reached a clear consensus that UVR is the main cause of viral destruction (Fuhrman \& Noble 1995), which may indirectly affect bacterial community structure and dissolved organic carbon (DOC) in marine ecosystems by causing the release of the host cell's contents (Middelboe \& Lyck 2002).

Most studies have focused on UVR effects on a single trophic level, but the effects of UVR are actually on the entire planktonic community. Relatively little information on the impact of solar UVR on species composition within natural ecosystems or on the interaction of organisms between trophic levels is available (Häder et al. 2011). Studies on UVR effects on a single trophic level can not be used to predict UVR impacts on the whole natural planktonic community structure (Bothwell et al. 1994). The shifts in the dominant microbial assemblages because of the variation in UVR exposure may modulate carbon allocation in the microbial loop. For example, the shifts in the balance of bacterial respiration and phytoplankton production likely determine whether there is a $\mathrm{CO}_{2}$ sink or release in a marine ecosystem (Conan et al. 1999). Intensive debate has occurred on whether oligotrophic marine systems are autotrophic or heterotrophic (Dortch \& Packard 1989). Little attention has been paid to whether UVR regulates autotrophic or heterotrophic processes. Thus, the simultaneous study of UVR effects on both phytoplankton and bacteria is helpful to understand how UVR changes the microbial structure and carbon allocation by promoting tolerant species and reducing sensitive ones.

The South China Sea is the second largest inland sea and is connected to the Pacific Ocean by the Luzon Strait between Taiwan and the Philippines. Solar radiation including UVR in the South China Sea is stronger than that in temperate and polar zones because of the low zenith angles and low ozone concentrations in this area (Madronich 1993); hence the South China Sea is an ideal location to explore the effects of high UVR on the microbial assemblages. Previous studies have shown that ultraviolet-B (UVB) inhibition on phytoplankton photosynthesis in the South China Sea was $~ 10$ to $24 \%$ in the whole water column in coastal waters on sunny days (Helbling et al. 2003, Gao et al. 2007). However, UVR effects on other microbial assemblages (such as bacteria and viruses) are still unknown in the South China Sea, let alone the comparison of their sensitivities to UVR.

Our main objectives were to (1) compare primary production (PP), bacterial production (BP) and viral decay rates (VDR) with full solar radiation, i.e. photosynthetically active radiation (PAR) and UVR, and only PAR (without UVR) and (2) compare the sensitivities of bacteria, phytoplankton and viruses to UVR. These objectives are important in assessing the possible impacts of UVR on biogeochemical processes in the coastal and offshore oligotrophic subtropical South China Sea.

\section{MATERIALS AND METHODS}

\section{Sampling and experimental setup}

A cruise was conducted on the RV 'Shiyan II' of the South China Sea Institute of Oceanology during September 5 to 22,2005, stopping at 9 stations located in the northern South China Sea (Fig. 1). Temperature and salinity vertical profiles were determined with a YSI $^{\circledR} 6600$ CTD sensor. After seawater was dispersed into 11 Whirl-Pak bags with high UVR transmission, large zooplankton were removed using a $200 \mu \mathrm{m}$ mesh net. These Whirl-Pak bags allowed $67 \%$ transmittance (averaged over wavelengths of 290 to $320 \mathrm{~nm}$ ) of UVB, $75 \%$ transmittance of UVA (320 to $400 \mathrm{~nm}$ ) and $95 \%$ transmittance of PAR (400 to $700 \mathrm{~nm}$ ) (Noble \& Fuhrman 1997).

Water samples were collected from depths of 100, 50,10 and $0 \%$ of surface full solar radiation and were incubated under approximately the same light conditions from where they were obtained by using different neutral density screening. Incubations were conducted for $5 \mathrm{~h}$ from $\sim 10: 00$ to $\sim 15: 00 \mathrm{~h}$ for the measurements of BP, PP and VDR with UVR + PAR (full solar radiation) and without UVR (PAR treatments). UVR transmittance of wavelengths $<400 \mathrm{~nm}$ was blocked by covering the sample with Melinex film (DuPont Products). These Whirl-Pak bags covered with Melinex (PAR treatments) were exposed to 


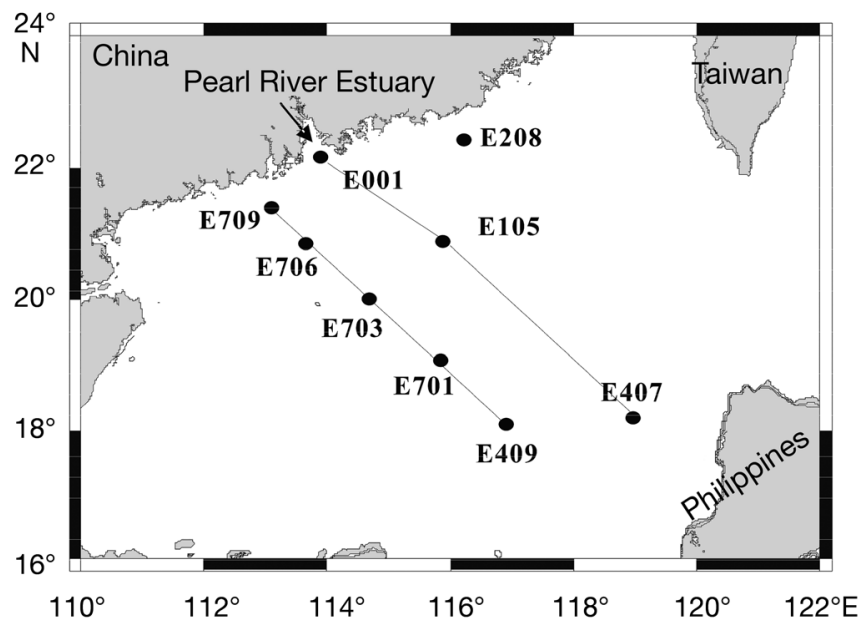

Fig. 1. Study area showing the locations of (black circles) sampling stations along 2 transects which were conducted from coastal (Stn E001 in the Pearl River estuary and Stn E709) to offshore waters (Stns E407 and E409) in the northern South China Sea (SCS) during September 2005. An incubation experiment was also conducted at Stn E208

solar radiation and incubated in a deck incubator cooled by surface seawater that did not capture the small temperature difference between deep (22 to $26^{\circ} \mathrm{C}$ ) and surface $\left(27\right.$ to $\left.29^{\circ} \mathrm{C}\right)$ water.

The conditions of our experimental manipulation had some deviation from in situ natural seawater. The ratio of UVR/PAR under neutral density screens would be different from that of the in situ natural seawater because the light attenuation coefficient is higher for UVR than PAR in seawater.

\section{Measurements of solar radiation}

A vertical profile of solar radiation was measured with an IL 1700 radiometer (International Light) and with 3 different submersible, broad-band, photodiode sensors (UVA, UVB and PAR).

\section{Measurements of biological parameters}

Chlorophyll a ( $\mathrm{chl}$ a) fluorescence was measured at the surface with a YSI ${ }^{\circledR} 6600$ sensor and chl $a$ of experimental water samples was measured using the in vitro fluorometric method with acetone extraction on a Turner Designs TD700 fluorometer (Knap et al. 1994).

For primary production, 10 to $20 \mu \mathrm{Ci} \mathrm{NaH}{ }^{14} \mathrm{CO}_{3}$ (14.8 to $74 \mathrm{kBq}$ ) was added in dim light to seawater $(50 \mathrm{ml})$ from depths of $100,50,10$ and $0 \%$ of surface light and incubated in Whirl-Pak bags for $5 \mathrm{~h}$ under full solar radiation (PAR + UVR) and PAR only. Triplicate bags were wrapped with different layers of screening that provided light fields corresponding to approximately 100, 50, 10 and $0 \%$ (i.e. darkness) of surface irradiance. The dark bottle for the control was wrapped in aluminum foil and placed in a black cloth bag. The incubation was terminated by filtering through a $25 \mathrm{~mm}$ Whatman GF/F filter and the filters were kept frozen $\left(-20^{\circ} \mathrm{C}\right)$ until they were analyzed within 1 mo following the Joint Global Ocean Flux Study (JGOFS) protocols (Knap et al. 1994). The filters were put into scintillation vials containing $0.2 \mathrm{ml}$ of $0.5 \mathrm{~N} \mathrm{HCl}$ for $12 \mathrm{~h}$ in order to remove inorganic carbon. After the addition of $10 \mathrm{ml}$ of scintillation cocktail (Hi-Safe) to each vial, samples were counted on a Perkin-Elmer Wallac 1414 liquid scintillation counter. Ambient dissolved inorganic carbon (DIC) was measured with an infra-red (IR) detector (Li-Cor 6252) using a DIC analyzer (AS-C2, Apollo SciTech), and bicarbonate incorporation rate was converted to $\mu \mathrm{g} \mathrm{C} \mathrm{l}^{-1} \mathrm{~h}^{-1}$ according to Knap et al. (1994). The use of GF/F filters may result in the underestimation of the primary production, as Prochlorococcus in oceanic waters might not be retained on GF/F filters efficiently.

Bacterial abundance (BA) was determined using the 4',6-diamidino-2-phenylindole (DAPI) direct count method (Porter \& Feig 1980). Samples (2 ml) were collected in micro-centrifuge tubes (Axygen) from separate Whirl-Pak bags, fixed with $2 \%$ (final concentration) formaldehyde, and filtered onto a $0.22 \mu \mathrm{m}$ polycarbonate membrane filter (Poretics). Bacterial cells were observed with an epifluorescence microscope (Olympus BX41) with blue excitation (485 $\mathrm{nm}$ ) and recorded as digital images. Stained bacterial cells in the digital images were acquired and counted with Image Pro ${ }^{\circledR}$ Plus (MediaCybernetics) software.

BP was determined as described by Simon \& Azam (1989). The subsamples were collected into $2 \mathrm{ml} \mathrm{mi-}$ cro-centrifuge tubes (Axygen) from separate WhirlPak bags after a $5 \mathrm{~h}$ incubation and incubated for $1 \mathrm{~h}$ in the dark to determine leucine incorporation. ${ }^{3} \mathrm{H}-$ leucine (final concentration $30 \mathrm{nmol}^{-1}$; specific activity $55.9 \mathrm{Ci} \mathrm{mmol}^{-1}$ ) was added to $2 \mathrm{ml}$ subsamples (triplicate) with 1 control fixed by $5 \%$ tri-chloroacetatic acid (TCA), and the linearity of the incorporation of leucine was tested in a separate time series experiment (data not shown). The incubation was terminated by adding TCA ( $5 \%$ final concentration). After centrifugation and aspiration of the supernatant, pellets were rinsed and centrifuged twice with $1 \mathrm{ml}$ of $5 \%$ TCA, and then scintillation cocktail was added to the 
vial. The incorporated ${ }^{3} \mathrm{H}$ was determined using a Perkin-Elmer Wallac 1414 liquid scintillation counter. Conversion factors (CFs) for estimating cell production from rates of leucine incorporated were empirically derived from dilution culture experiments (Hoch \& Kirchman 1993). Two experiments were conducted to determine the in situ CF (data not shown), and the estimated CFs were $\sim 2 \pm 1.2 \mathrm{~kg} \mathrm{C}$ mol leucine ${ }^{-1}$.

Viral samples were fixed with glutaraldehyde ( $2.5 \%$ final concentration) and stored in liquid nitrogen. The samples for enumeration of viruses were thawed immediately before analysis, diluted 10- to 100-fold in tris-EDTA (TE) buffer (pH 8) and stained with SYBR green I (Molecular Probes) at $80^{\circ} \mathrm{C}$ in the dark for $10 \mathrm{~min}$. Fluorescent microspheres (Molecular Probes) with a diameter of $1 \mu \mathrm{m}$ were added to all samples as an internal standard. The discriminator was set on green fluorescence, and the samples were analyzed at a viral event rate of between 100 and $1000 \mathrm{~s}^{-1}$. Viral abundance was determined using flow cytometry (FACSCalibur, Becton Dickinson) according to methods described by Brussaard (2004). VDR was calculated as the percent decrease of viral abundance divided by the incubation period and assessed according to the method of Noble \& Fuhrman (1997). In detail, 20 to $100 \mathrm{ml}$ water samples were filtered $(0.2 \mu \mathrm{m}$ pore-size) and the filtrates were incubated for $6 \mathrm{~h}$ under full solar radiation and PAR only treatments. Subsamples $(2 \mathrm{ml})$ were taken every 1 to $2 \mathrm{~h}$ and processed for viral counts using flow cytometry. From the decrease in viral abundance over time, the viral decay rates were calculated by fitting a linear regression of the logged viral abundance to time. The slope of the line is the VDR $\left(\mathrm{h}^{-1}\right)$.

\section{Calculations and statistics}

UVA diffuse attenuation coefficient $\left(K_{\mathrm{d}}\right)$ was calculated according to the equation: $E_{Z}=E_{0} \exp \left(-K_{\mathrm{d}} \times Z\right)$ where $E_{Z}$ and $E_{0}$ are downwelling irradiances at depths $Z$ and 0 , respectively (Kirk 1994). Percent UVR inhibition of $\mathrm{PP}=\left(\mathrm{PP}_{\mathrm{PAR}}-\mathrm{PP}_{\text {full }}\right) / \mathrm{PP}_{\mathrm{PAR}}$, where $\mathrm{PP}_{\mathrm{PAR}}$ is $\mathrm{PP}$ under PAR only and $\mathrm{PP}_{\text {full }}$ is $\mathrm{PP}$ under full solar radiation. The estimates of inhibition of UV on BP are similar to those on PP (see equation above). The significance of spatial differences was assessed using an analysis of variance followed by a means comparison (t-test) or 1-way ANOVA test at a significance level of $\mathrm{p}=0.05$. The error bars represent a pooled sample standard deviation of the means. In addition, the Pearson chi-squared test was used to obtain the correlation coefficient. All statistical analyses were performed using SPSS statistical software (IBM).

\section{RESULTS}

\section{Environmental parameters of the study area}

Daily solar radiation was relatively strong (1500 to $2100 \mathrm{~J} \mathrm{~cm}^{-2}$ ) and higher than the average daily solar radiation $\left(1400 \mathrm{~J} \mathrm{~cm}^{-2}\right)$ for the whole year in 2005 (www.weather.gov.hk). The UVR dose (UVA + UVB) varied from 70 to $120 \mathrm{~J} \mathrm{~cm}^{-2}$ during the incubation period (Fig. 2). UVA diffuse attenuation coefficients generally decreased from Stns E001 to E407, which significantly correlated with salinity $\left(r^{2}=0.9, p<0.05\right)$. UVA attenuation depths ( $1 \%$ of surface UVA) varied from $1.7 \mathrm{~m}$ at Stn E001 to $60 \mathrm{~m}$ at Stn E407 (Table 1). The lowest UVA penetration depth, $1.7 \mathrm{~m}$ at E001 (the highest attenuation coefficient, $K_{\mathrm{d}}, 2.7 \mathrm{~m}^{-1}$ ) resulted from the influence of the freshwater discharge from the Pearl River estuary.

Salinity increased gradually from the Pearl River estuary (Stn E001) to offshore, ranging from 23 at coastal Stn E001 to 34 at offshore Stn E409 (Fig. 3). There were only small variations in surface temperature among all these stations, which ranged from $27^{\circ} \mathrm{C}$ at Stn E001 to $29^{\circ} \mathrm{C}$ at Stn E701 (Fig. 3).

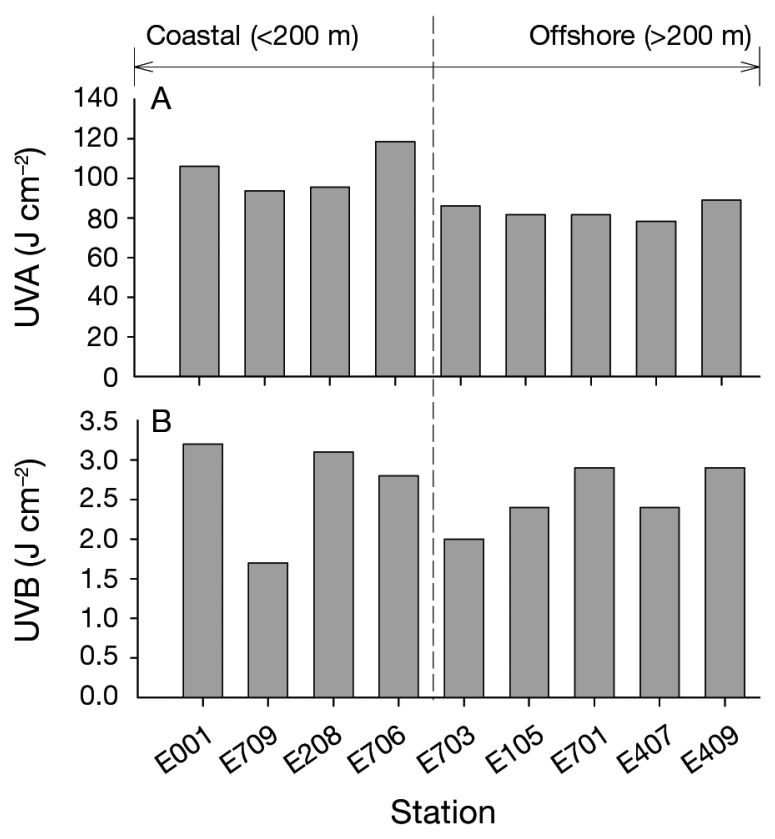

Fig. 2. Exposure doses of (A) UVA and (B) UVB at the surface at 9 stations in the South China Sea, shown in order of increasing salinity (see Table 1) 
Table 1. Depth, temperature, salinity and chlorophyll a ( $\mathrm{chl} \mathrm{a)} \mathrm{in} \mathrm{the} \mathrm{surface} \mathrm{water} \mathrm{and} \mathrm{diffuse} \mathrm{attenuation} \mathrm{coefficient} \mathrm{of} \mathrm{UVA}$ $\left(K_{\mathrm{d}}\right)$ and attenuation depths of $1 \%$ surface UVA $\left(Z_{1}\right)$ observed at 9 stations in the South China Sea. nd: no data. $\mathrm{n}=1$

\begin{tabular}{|lcccccccc|}
\hline Stns & $\begin{array}{c}\text { Latitude } \\
\left({ }^{\circ} \mathrm{E}\right)\end{array}$ & $\begin{array}{c}\text { Longitude } \\
\left({ }^{\circ} \mathrm{N}\right)\end{array}$ & $\begin{array}{c}\text { Depth } \\
(\mathrm{m})\end{array}$ & $\begin{array}{c}\text { Temperature } \\
\left({ }^{\circ} \mathrm{C}\right)\end{array}$ & Salinity & $\begin{array}{c}\text { Chl } a \\
\left(\mu \mathrm{l}^{-1}\right)\end{array}$ & $\begin{array}{c}K_{\mathrm{d}} \\
\left(\mathrm{m}^{-1}\right)\end{array}$ & $\begin{array}{c}Z_{1} \\
(\mathrm{~m})\end{array}$ \\
\hline E001 & 22.00 & 114.00 & 20 & 27.9 & 23.5 & 3.0 & 2.70 & 1.7 \\
E709 & 21.50 & 113.50 & 40 & 29.0 & 32.1 & 2.9 & 0.62 & 7 \\
E208 & 22.20 & 116.30 & 40 & 29.4 & 33.2 & 0.2 & 0.33 & 14 \\
E706 & 20.75 & 114.25 & 80 & 28.9 & 33.9 & 0.1 & 0.41 & nd \\
E703 & 19.90 & 115.10 & 1180 & 29.1 & 33.9 & 0.1 & 0.24 & 20 \\
E105 & 20.60 & 116.40 & 450 & 29.1 & 34.0 & 0.1 & 0.11 \\
E701 & 19.00 & 116.01 & 3100 & 29.1 & 34.0 & 0.3 & 0.1 \\
E407 & 18.00 & 119.00 & 4150 & 28.1 & 34.1 & 0.1 & 0.12 \\
E409 & 18.10 & 117.00 & 3950 & 27.7 & 34.2 & 0.1 & 0.12 & 40 \\
\hline
\end{tabular}

\section{Biological parameters}

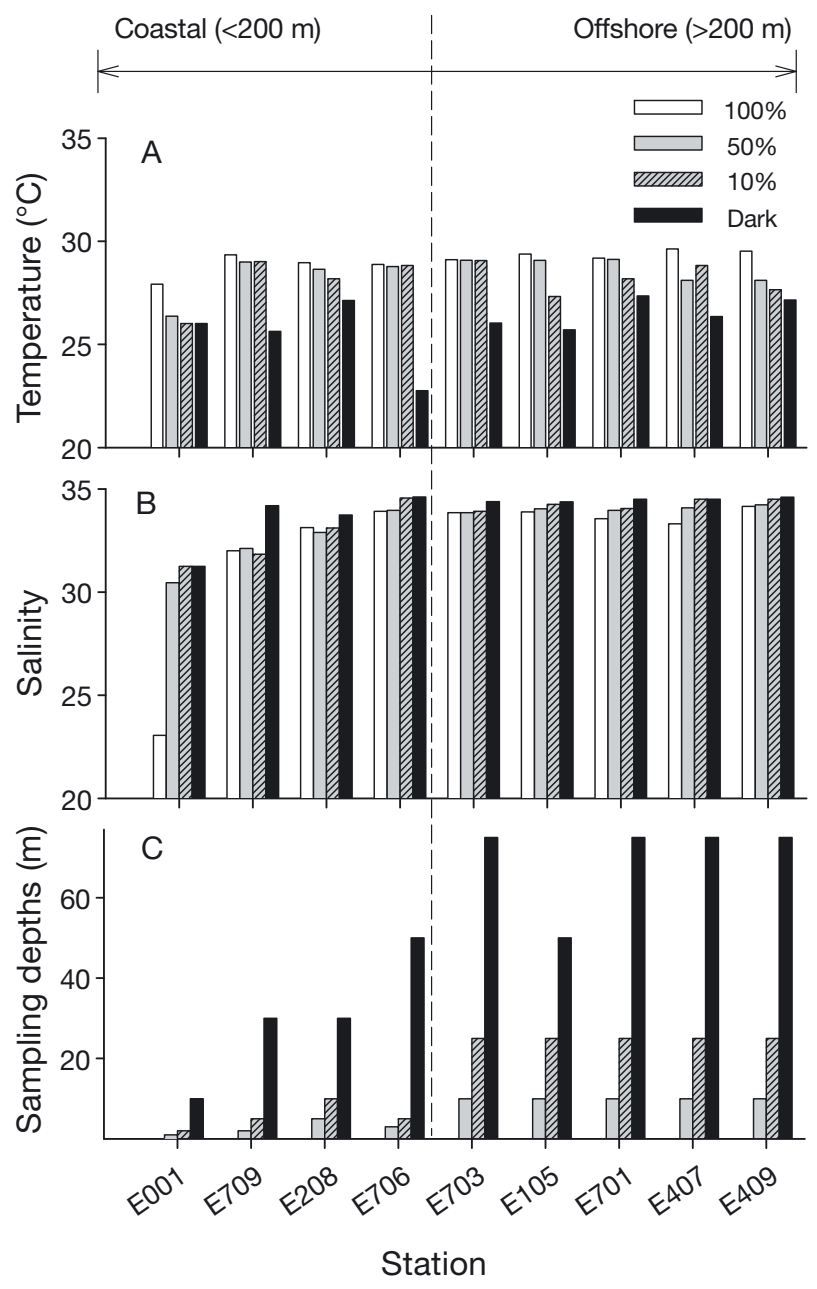

Fig. 3. (A) Temperature, (B) salinity, and (C) sampling depths corresponding to light depths of 100, 50, 10 and $0 \%$ (darkness) of full solar radiation (PAR + UVR) at 9 stations from coastal to offshore waters shown in order of increasing salinity. PAR: photosynthetically active radiation; UVR: ultraviolet radiation. $\mathrm{n}=1$
Chl $a$ and bacterial and viral abundances were often higher at coastal than offshore stations. Surface chl a was $3.0 \mathrm{\mu g} \mathrm{l}^{-1}$ at coastal Stn E001 and decreased to $\sim 0.1 \mathrm{ug} \mathrm{l}^{-1}$ at offshore Stn E703 (Table 1). Surface bacterial and viral abundances were 7 to $14 \times 10^{5}$ cells $\mathrm{ml}^{-1}$ and 0.8 to $2 \times 10^{7} \mathrm{ml}^{-1}$ in coastal waters, respectively, and 7 to $10 \times 10^{5}$ cells ml ${ }^{-1}$ and 2 to $10 \times 10^{7} \mathrm{ml}^{-1}$ in offshore waters, respectively (Fig. 4).

Under full solar radiation (UVR + PAR), the highest surface PP was $\sim 0.6 \mu \mathrm{g} \mathrm{Cl}^{-1} \mathrm{~h}^{-1}$ at coastal Stn E001 and decreased to $\sim 0.3 \mu \mathrm{g} \mathrm{Cl}^{-1} \mathrm{~h}^{-1}$ in the offshore stations (Fig. 5A). Surface PP was significantly higher than that in subsurface samples in coastal and offshore waters except at Stns E208 and E409 $(t=2.6$, $\mathrm{df}=25, \mathrm{p}<0.05)($ Fig. 5A).

The surface BP at Stn E001 was $~ 0.01 \mu \mathrm{g} \mathrm{C}^{-1} \mathrm{~h}^{-1}$

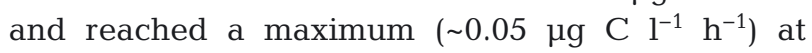
Stn E709 (Fig. 5B). Surface BP was low ( 0.02 $\mathrm{\mu g}$ $\mathrm{C}^{-1} \mathrm{~h}^{-1}$ ) at offshore Stns E701, E409 and E407. BP was often higher under $50 \%$ than $10 \%$ of full solar radiation at all these stations $(t=2.8, \mathrm{df}=13, \mathrm{p}<0.05)$ (Fig. 5B).

The coastal VDR at the surface were up to $0.1 \mathrm{~h}^{-1}$ at Stn E709, while VDR in the offshore waters were 0.01 to $0.11 \mathrm{~h}^{-1}$. VDR was usually higher under 100,50 and $10 \%$ of full solar radiation than in the dark $(\mathrm{t}=2.1, \mathrm{df}=25, \mathrm{p}<0.05)$ (Fig. 5C).

\section{UVR effects on PP, BP and VDR}

Significant UVR inhibition of PP and BP was observed in most samples (Fig. 6A). UVR inhibition of PP varied from $\sim 0$ to $52 \%$ (Fig. 6A). Surface PP decreased by $\sim 52 \%$ at Stn E001 because of the UVR exposure, which was the largest UVR inhibition of PP 


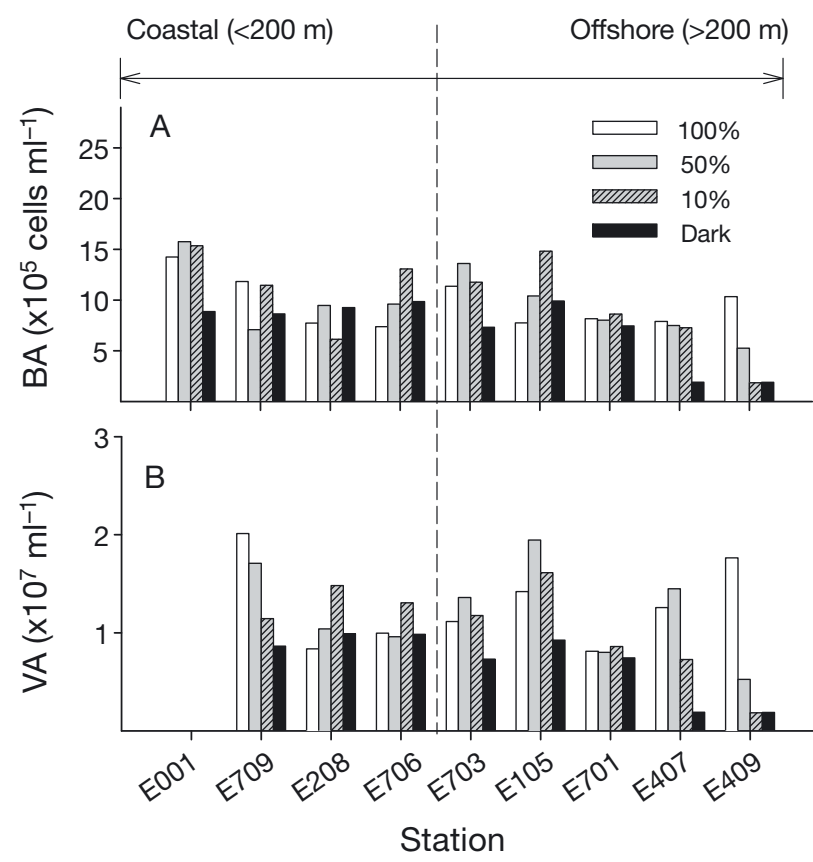

Fig. 4. (A) In situ bacterial abundance (BA) and (B) viral abundance (VA) under light depths of 100, 50, 10 and $0 \%$ (darkness) of full solar radiation (PAR + UVR, see Fig. 3 for definition) at 9 stations from coastal to offshore waters shown in order of increasing salinity. VA was not measured at Stn E001. $\mathrm{n}=1$

among all the measurements during this cruise (Fig. 6). The maximum inhibition of PP was not always at the surface, even though surface samples received a higher UVR dose (Fig. 6A). UVR inhibition of PP exhibited no correlation with UVA diffuse attenuation coefficient as well as with UVR dose at the surface (data not shown).

Due to the UVR exposure, the inhibition of BP was highest at E001 and was not always higher at the surface than the subsurface (Fig. 6B). At coastal Stn E208, BP was not inhibited by UVR at $50 \%$ of full solar radiation but increased by approx. $10 \%$ (negative inhibitory value). UVR inhibition of BP had no correlation with UVR dose and diffuse attenuation coefficient (data not shown).

In contrast to the UVR inhibition of PP and BP, VDR increased under full solar radiation compared to the PAR treatment. VDR was highly variable, ranging from $\sim 0$ to $120 \%$ (Fig. 6C). The percent increase in VDR was significantly correlated with the UVA diffuse attenuation coefficient at all light depths ( $\mathrm{r}=$ $0.4-0.6, \mathrm{df}=9, \mathrm{p}<0.05$ ) (Fig. 7). In addition, the slope of this regression was steeper in subsurface water $(-126)$ (Fig. 7B) than surface water (-49) (Fig. 7A), suggesting that subsurface viruses were more influ- enced by the variations in the diffuse attenuation coefficient than surface viruses.

\section{Comparison of UVR effects between PP, BP and VDR}

A total of 20 out of 26 data points were above the 1:1 line for the inhibition of $\mathrm{BP}$ versus $\mathrm{PP}$, indicating that BP was inhibited more than PP $(t=2.3, \mathrm{df}=25$, $\mathrm{p}<0.05$ ) (Fig. 8A). Similarly, the loss of viral abundance was often higher than the inhibition of PP because of the UVR exposure in 16 out of 24 samples, although not significantly higher $(t=1.8, \mathrm{df}=25$,

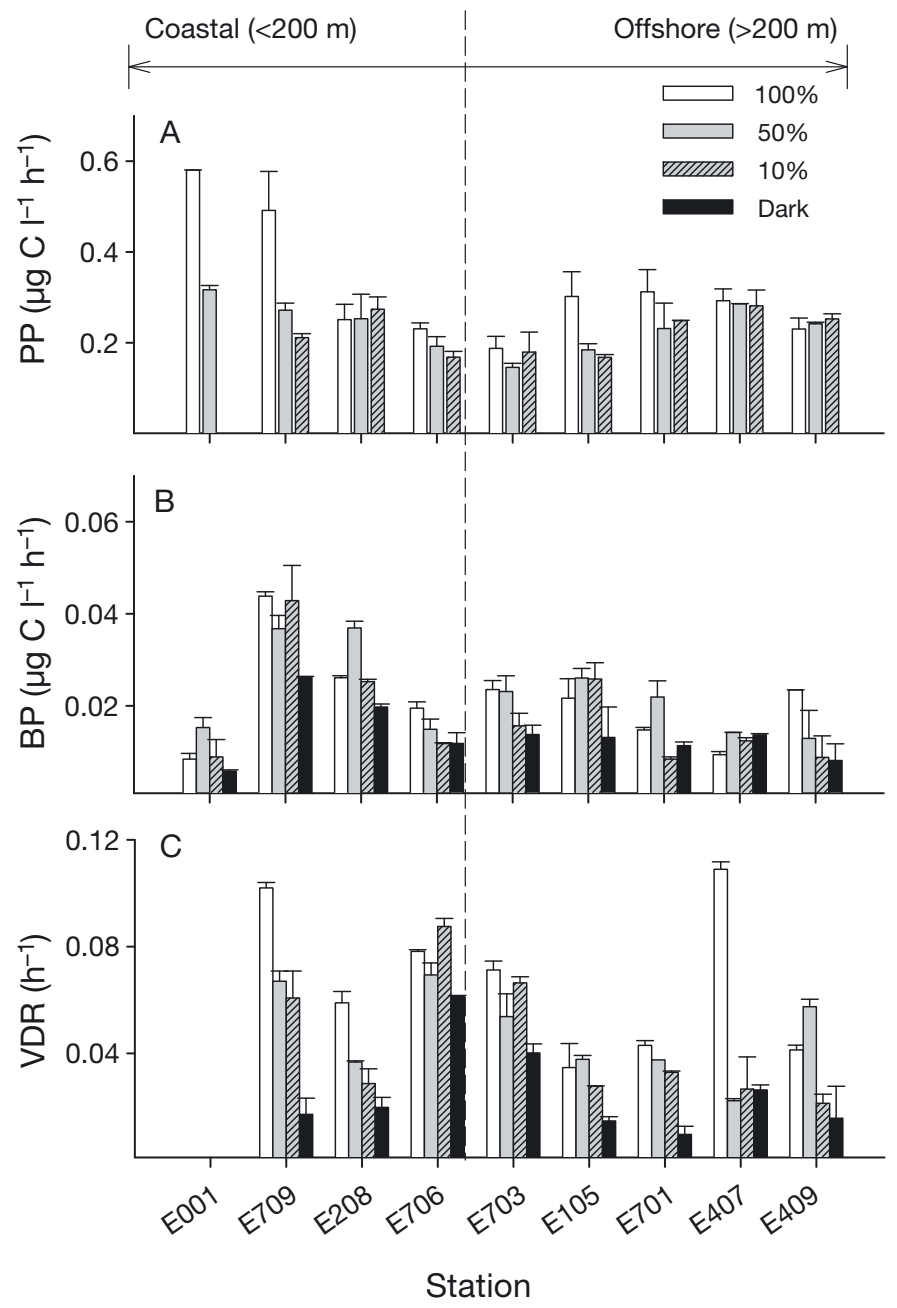

Fig. 5. Mean $( \pm 1 \mathrm{SD})(\mathrm{A})$ primary production $(\mathrm{PP})$, (B) bacterial production (BP), and (C) viral decay rates (VDR) under 100, 50, 10 and $0 \%$ (darkness) light depths for full solar radiation (PAR + UVR, see Fig. 3 for definition) at 9 stations from coastal to offshore waters shown in order of increasing salinity. At station E001, PP in $10 \%$ light depth was not measured because of shallow depth, and VDR was not measured. $n=3$ 


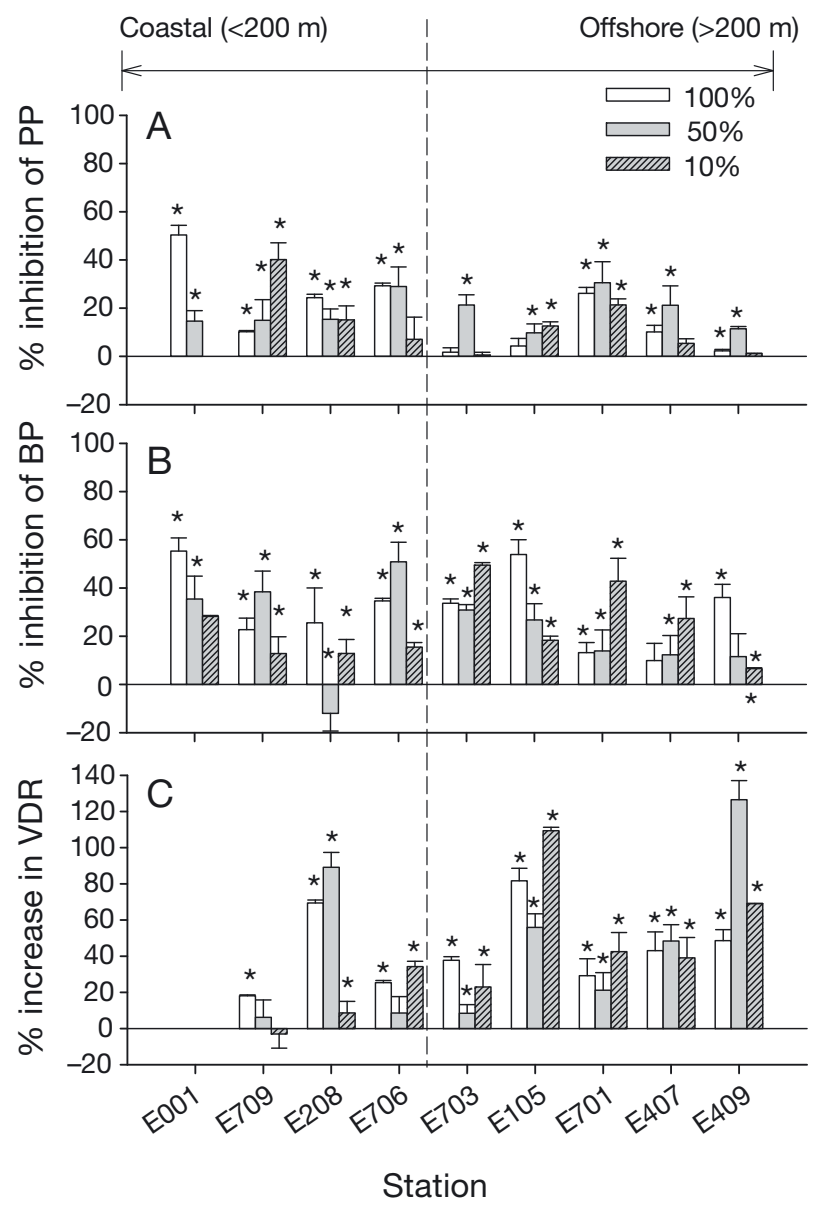

Fig. 6. Mean ( $\pm 1 \mathrm{SD}$ ) percent UVR inhibition of $(\mathrm{A})$ primary production (PP), (B) bacterial production (BP) and (C) \% increase in viral decay rates (VDR) under light depths of 100 , $50,10 \%$ of full solar radiation (PAR + UVR, see Fig. 3 for definition). Note that the scale on the $y$-axis is different between (B) and (C). UVR inhibition of VDR was not measured at Stn E001. $\mathrm{n}=3 .{ }^{*} \mathrm{p}<0.05$ between samples under full solar radiation and PAR treatments. At station E001, PP in $10 \%$ light depth was not measured because of shallow depth, and VDR was not measured $\mathrm{p}<0.05$ ) (Fig. 8B). However, UVR effects on VDR, BP and PP were not significantly higher under 100\% than $10 \%$ and $50 \%$ of full solar radiation $(t=1.7$, df $=26, p<0.05$ ) (Fig. 8A,B).

BP was significantly correlated with PP under UVR + PAR and in the PAR treatment (Fig. 9A,B). The test for homogeneity of the regression of BP versus PP showed that the slopes and the correlation coefficients were not significantly higher in PAR treatment than under full solar radiation (Fig. 9).

\section{DISCUSSION}

\section{Factors regulating UVR effects}

In offshore waters, UVR inhibition of PP, BP and the increase in VDR due to UVR was not always lower under 10 and $50 \%$ of full solar radiation than under $100 \%(t=1.8, \mathrm{df}=9, \mathrm{p}<0.05)$. UVR inhibition might be higher in our incubation than the natural condition, especially at lower irradiances, because the experimental manipulation using neutral density filters would enhance the proportion of solar radiation with shorter wavelengths. Hence, the inhibition of $\mathrm{BP}, \mathrm{PP}$ and the increase in VDR due to UVR was not always significantly correlated with UVR dose in our study ( $\mathrm{r}=0.1, \mathrm{p}>0.05, \mathrm{n}=20$ to 24 , data not shown).

UVR effects on these microbes did not only depend on the UVR dose (Cullen \& Lesser 1991), but also was influenced by taxonomic composition, physiological status, light history, repair mechanisms and genetic acclimation (Helbling et al. 2003). For example, Prochlorococcus dominated the more oceanic and oligotrophic waters in the northern South China Sea, whereas Synechococcus was more important in mesotrophic areas (eddies, offshore jet and river
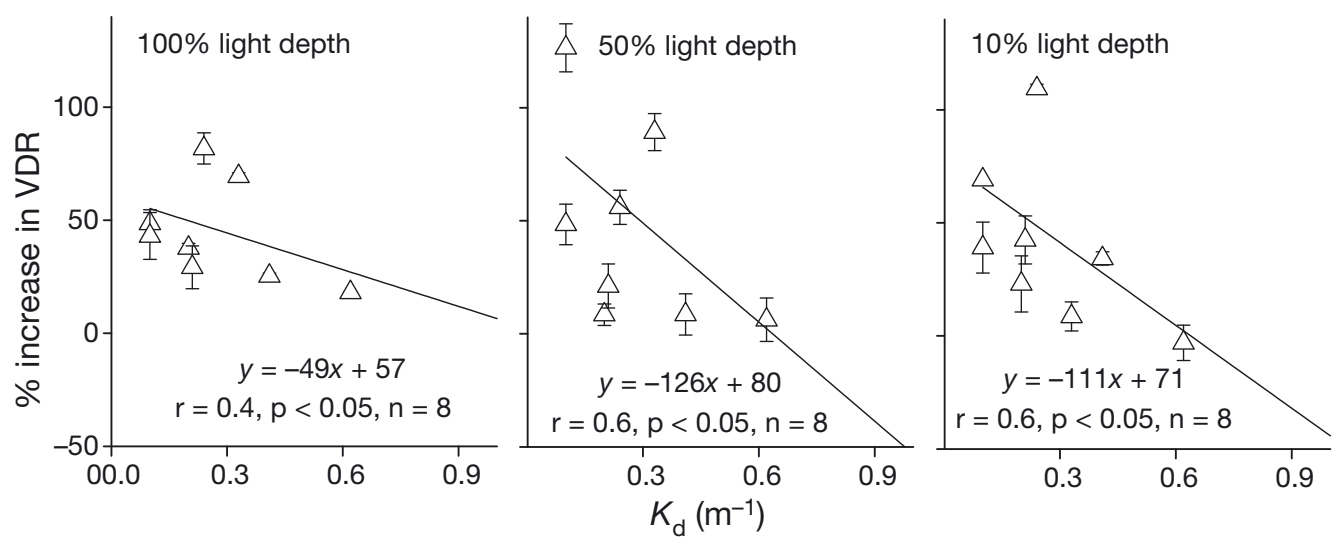

Fig. 7. Correlations of diffuse attenuation coefficient of ultraviolet radiation $\left(K_{\mathrm{d}}\right)$ with mean $( \pm 1$ SD) viral decay rates (VDR) under 100, 50 and $10 \%$ of surface solar radiation. $\mathrm{n}=8$ 

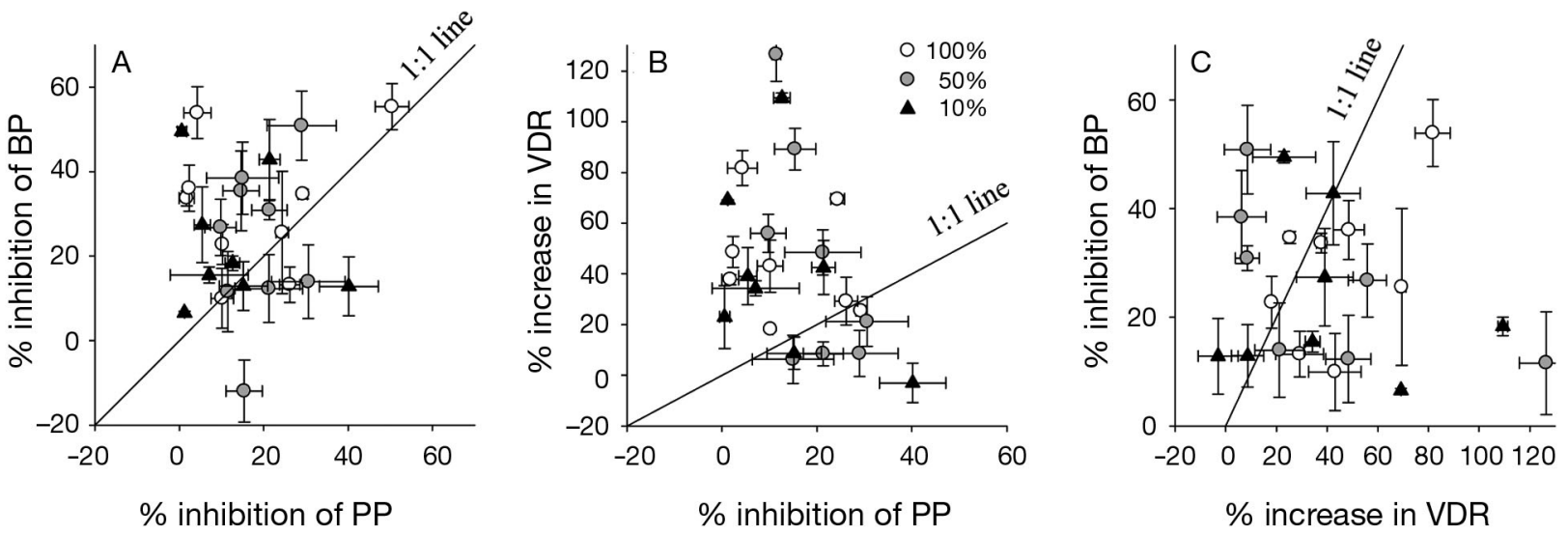

Fig. 8. Comparisons of ultraviolet radiation (UVR) effects on mean $( \pm 1 \mathrm{SD})$ bacterial production (BP), primary production $(\mathrm{PP})$ and viral decay rate (VDR) at all 9 stations and 3 light depths (100, 50 and 10\% of full surface radiation). (A) Inhibition of bacterial production (\%) versus inhibition of primary production (\%). (B) Increase in viral decay rate (\%) versus inhibition of primary production. (C) Inhibition of bacterial production (\%) versus increase in viral decay rate (\%). Solid lines represent the $1: 1$ ratio. $\mathrm{n}=24$ to 27
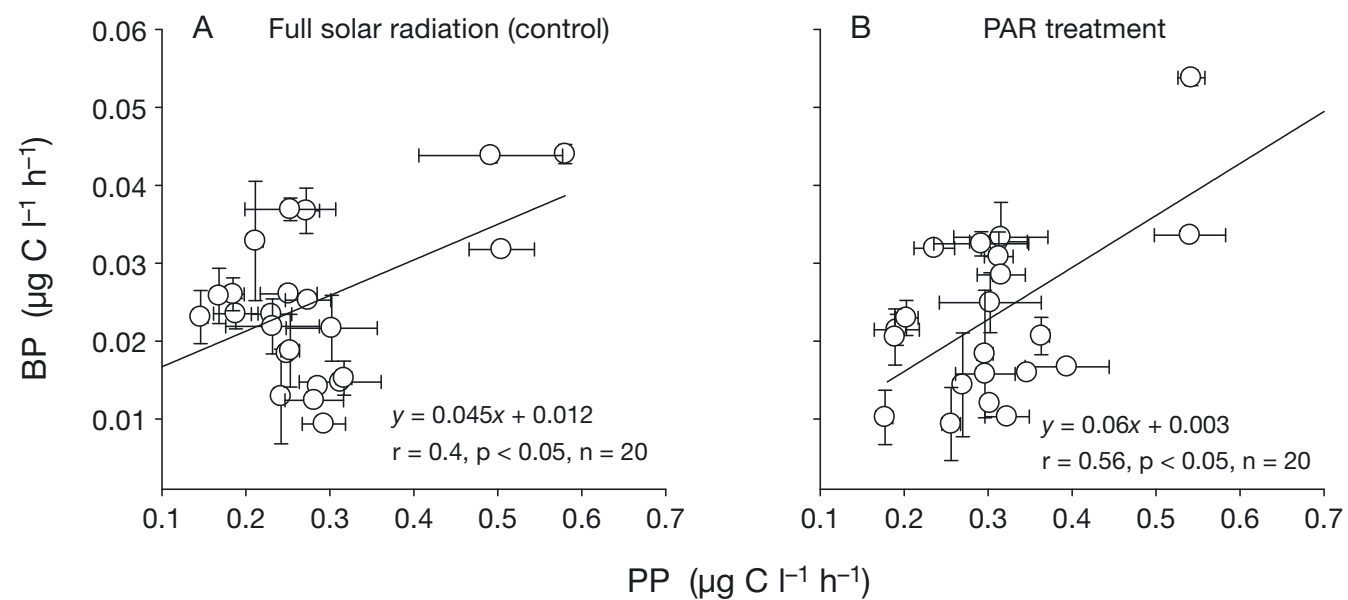

Fig. 9. Regression plots of mean $( \pm 1 \mathrm{SD})$ primary production $(\mathrm{PP})$ versus mean $( \pm 1 \mathrm{SD})$ bacterial production $(\mathrm{BP})$ under $(\mathrm{A})$ full solar radiation (UVR + PAR, see Fig. 3 for definition) and (B) PAR only treatments. $\mathrm{n}=24$ to 27

plume) (Chen et al. 2009). The distribution patterns of these picoplankton may affect UVR inhibition, as some studies have reported that Synechococcus and eukaryotes were more resistant to UVR than Prochlorococcus in oligotrophic waters (Llabrés \& Agustí 2006, Agustí \& Llabrés 2007). However, our study showed that UVR inhibition of PP was not significantly higher in oceanic and oligotrophic waters than coastal and estuarine waters $(t=1.1, \mathrm{df}=28, \mathrm{p}<0.05)$ (Fig. 6A).

Vertical mixing often influenced the UVR effects on microorganisms, and deeper phytoplankton were less resistant to UVR than surface cells because of their different light history (Helbling et al. 2003).
Vertical mixing such as upwelling and downwelling was likely an important factor regulating the microbial sensitivities to UVR in the South China Sea. During the same cruise, He et al. (2009) observed that upwelled cold and saline water was present at Stn E001 and downwelling was present at Stn E105. In our study, UVR inhibition of PP at Stn E001 was higher than that at Stn E105 ( $t=3.1, \mathrm{df}=4, \mathrm{p}<0.05$ ) even though the inhibition of PP was normalized in terms of UVR dose (data not shown). Hence, surface phytoplankton in upwelled waters (Stn E001) were more sensitive to UVR exposure possibly because of their previous light history in deeper waters $(t=3.4$, $\mathrm{df}=4, \mathrm{p}<0.05)$ (Fig. 6A). Similarly, previous studies 
also reported that bacteria in surface water samples showed a more effective photorepair mechanism than subsurface assemblages in the upwelling system off central-southern Chile (Hernández et al. 2006). However, in our study, UVR inhibition of surface BP was not significantly different between Stns E001 and E105 ( $t=0.8, \mathrm{df}=4, \mathrm{p}>0.05$ ) (Fig. 6B). Hence, surface bacteria in upwelled and downwelled waters did not exhibit a difference in resistance to UVR in our study, although vertical mixing has been shown to influence the DNA damage and viability of bacteria (Jeffrey et al. 1996, Hernández et al. 2006, Bertoni et al. 2011).

The freshwater discharge is characterized by heavy organic loads in the Pearl River estuary, which influences its optical properties (Wang et al. 2010). As a result, the UVA diffuse attenuation coefficient was high at Stn E001 and adjacent waters (Table 1). Hence, although the UVR dose at the surface was not considerably different during our incubations at 9 stations, UVR penetration was quite different between coastal and offshore waters and was much lower near the Pearl River estuary (Table 1). There was a significant correlation between VDR and diffuse attenuation coefficient, and VDR were higher in offshore waters (Fig. 7C) where there was higher light penetration. However, neither BP nor PP was significantly correlated with the diffuse attenuation coefficient (data not shown). Hence, viruses appeared to be more affected by light attenuation than phytoplankton and bacteria possibly because the waters with high light penetration provided less protection for viruses from the UVR exposure. In addition, viruses have no repair mechanism, although Weinbauer et al. (1997) reported that lightdependent repair, probably photoreactivation, compensated for a large fraction of sunlight-induced DNA damage in natural viral communities. Hence, viruses are more sensitive to variations in water optical properties than bacteria and phytoplankton.

In addition to optical properties, the Pearl River estuary also influenced the chemical properties of the adjacent waters, especially the inorganic N:P ratios because the upstream freshwater from the Pearl River estuary exhibits a high N:P ratio (100:1), which often results in P-limitation for surface phytoplankton and bacteria (Yin et al. 2001, Yuan et al. 2011b,c). Both phytoplankton and bacteria were also strongly inhibited by UVR at Stn E001 (Fig. 6A,B), where N:P ratio was $>30: 1$ as reported by $\mathrm{He}$ et al. (2009). Further studies are needed to determine if the dual stress of UVR and P-limitation near the Pearl River estuary makes the bacteria and phytoplankton less resistant to UVR effects (Fig. 6). Previous studies showed that P-limited phytoplankton were often less resistant to UVR inhibitory effects (Doyle et al. 2005). Medina-Sánchez et al. (2002) also reported that UVB radiation inhibited bacteria when they were strongly P-deficient, whereas UVB exerted no direct effect on bacterial activity when they were not P-limited. A recent study showed that phosphorus amendment and UVR exposure had a synergistic negative effect on phytoplankton (Carrillo et al. 2008).

\section{UVR effects on viral decay rates (VDR)}

While $\sim 40 \pm 35 \%$ of viral mortality was due to UVR effects at the surface in the South China Sea, VDR was relatively low (0.01 to $0.11 \mathrm{~h}^{-1}$ ) (Fig. 6) in comparison with high VDR of 0.4 to $0.8 \mathrm{~h}^{-1}$ in the Gulf of Mexico (Wilhelm et al. 1998) and 0.05 to $0.1 \mathrm{~h}^{-1}$ in Santa Monica Bay (Noble \& Fuhrman 1997). The low VDR might be due to the fact that viruses from sunnier regions apparently show more adaptation and resistance to light damage (Noble \& Fuhrman 1997). However, because of the sparse historical data on the UVR contribution to VDR in other offshore regions, the comparison of viral sensitivity to UVR in the South China Sea with other oligotrophic offshore systems requires further investigation based on the same UVR dose and spectra during the same month.

Viruses play an important role in the biogeochemical cycling of carbon and nitrogen in the ocean (Fuhrman 1999, Suttle 2005, 2007) and can be modulated by variations in UVR dose. Assuming that all viruses were bacteriophages because algal viruses do not significantly contribute to total viral abundance (Wommack \& Colwell 2000), the viral contribution to bacterial mortality is equal to [VDR $\times$ viral abundance / (burst sizes $\times$ bacterial abundance)] (Culley \& Welschmeyer 2002). A range of burst sizes between 50 and 100 viruses for one bacterial cell was used in our calculations (Bratbak et al. 1990, Wilhelm et al. 2002). Because surface VDR varied from $\sim 0.01$ to $0.11 \mathrm{~h}^{-1}$, surface viral activity could contribute to about 0.4 to $1 \% \mathrm{~h}^{-1}$ of the surface bacterial mortality. If bacterial biomass (C) was estimated using a CF of 30 and $12 \mathrm{fg} \mathrm{C} \mathrm{Cell}^{-1}$ for coastal and offshore waters, respectively (Fukuda et al. 1998), the surface bacterial mortality because of viral lysis was approximately equal to 20 to $50 \%$ BP. About $30 \%$ of the viral mortality was due to UVR exposure at the surface, which partially reduced the viral effect on bacteria and hence indirectly reduced BP mortality. 


\section{Implications for UV effects on trophic levels}

Vidussi et al. (2011) reported that increased UVB only exerted moderate and insignificant effects on the entire plankton food web because of the moderate natural daily UVB dose combined with a relatively UVB-resistant plankton community in early spring in the northern Mediterranean. In contrast to their moderate effects, our results showed that strong UVR inhibited phytoplankton, bacteria and viruses, as our experiments were conducted under the whole UVR spectra rather than UVB only. In agreement with the study by Plante \& Arts (2000), which showed competitive advantages of phytoplankton over bacteria under UVR in continuous cultures, our results also showed that bacteria were more inhibited by UVR than phytoplankton were.

However, the UVR effects on BP and PP were not directly comparable in our study. In contrast to UVR effects on VDR and PP, which were estimated based on accumulative effects over a $5 \mathrm{~h}$ exposure, the effects of UVR on BP were measured with ${ }^{3} \mathrm{H}$-leucine within $1 \mathrm{~h}$ in the dark after a $5 \mathrm{~h}$ exposure to UVR. Because bacteria can partially recover from UVR damage in the dark (Jeffrey et al. 1996), the inhibition of UVR on BP would be expected to be higher if BP was measured similar to PP by incubating the sample with radiolabeled substrates during the whole $5 \mathrm{~h}$ exposure. In addition, Vaughan et al. (2010) also showed that inhibition of UVR on BP was less when radiolabeled substrates were added after exposure to UVR, compared to simultaneous exposure and incorporation. Therefore, the UVR effects on BP might be underestimated in our study because BP was measured with ${ }^{3} \mathrm{H}$-leucine in the dark at the end of the exposure. However, if there is an underestimate, then our results even more strongly support our conclusion that UVR inhibition of BP was significantly higher than PP in most of the samples.

The slope and correlation coefficients between BP versus PP were lower under full solar radiation than under the PAR treatment (Fig. 9), suggesting that the correlation between BP and PP became weakened because of UVR. Several previous studies also suggested that the phytoplankton-bacteria relationship can be controlled by UVR based on the following evidence. (1) UVR exerted a negative effect on primary production but strongly enhanced the absolute and percentage excretion of C (up to $60 \%$ ) (Carrillo et al. 2002). The availability of this excreted carbon for bacteria requires further study. (2) Bacteria may be indirectly affected by UVR through the trophic cascade. For example, UVR decreased the bacterivo- rous capability of nanoplankton and consequently reduced the predators on bacteria (Medina-Sánchez et al. 2006). In addition, phytoplankton would exhibit different responses in different nutrient states. For example, nutrient stress may weaken or mask the UVB stress (Xenopoulos et al. 2002), while a nutrient amendment (e.g. P addition) had a negative effect on phytoplankton subjected to UVR exposure (Carrillo et al. 2008).

An important question concerning the marine ecosystem functionality is whether it is autotrophic or heterotrophic, although the trophic state does not always determine whether the water is a source or sink of $\mathrm{CO}_{2}$ (Chen 2010, Yuan et al. 2011a). Bacterial respiration has a large contribution to the release of $\mathrm{CO}_{2}$ in coastal waters of the South China Sea (Yuan et al. 2010), while high phytoplankton production tends to enhance the biological pump by $\mathrm{CO}_{2}$ drawdown (Carlson et al. 1994). However, our study of BP was not sufficient to estimate the effects of UVR on heterotrophic activities because a large part of the bacterial carbon demand is respired and bacterial respiration may not be inhibited in the same way as $\mathrm{BP}$. In addition, BP measured after a $5 \mathrm{~h}$ incubation would not represent the activities during the whole day because bacteria are able to repair their UV damage during the night. Therefore, net community production (NCP), which includes the activities of all other organisms (e.g. zooplankton), would be a more useful parameter to determine in order to understand the effects of UVR on trophic state. For example, NCP was severely inhibited by UVR at the surface in mesotrophic low salinity waters adjacent the Rhône River (Joux et al. 2009). Therefore, further experiments on NCP are needed to determine UVR effects on heterotrophy or autotrophy in the South China Sea.

In summary, the sub-tropical/tropical South China Sea is characterized by strong solar radiation and high UVR especially in summer. Hence it is important to determine strong UVR effects on the food web structure and the consequences on carbon flow. Our results showed that the effects of strong UVR on phytoplankton, bacteria and viruses were generally inhibitory in late summer in the northern South China Sea. UVR exposure decreased viral abundance, BP and PP by 30, 20 and $14 \%$, respectively. The inhibitory effects on phytoplankton, bacteria and viruses depended on the water optical and chemical properties, which were influenced by the Pearl River estuarine waters and the mixing with offshore waters. The comparison of phytoplankton and bacterial UVR inhibition indicated that there was a higher 
decrease in BP than PP because of the UVR exposure $(t=2.3, \mathrm{df}=25, \mathrm{p}<0.05)$ (Figs. 5, $6 \& 8)$. Therefore, UVR might shift a marine ecosystem to more phytoplankton dominance because of UVR exposure during the daytime.

Acknowledgements. This research was supported by a grant from the CAS/SAFEA International Partnership Program for Creative Research Teams (KZCX2-YW-T001), an Area of Excellence project (AoE/P-04/04) from Hong Kong, NSFC (41106107, 41176129 and 40806050) and LMEB201001. K.Y. acknowledges support by ARC DP110103155. We thank the South China Sea Institute of Oceanology (SCSIO), CAS, Guangzhou for the opportunity to join their open cruise. Our special thanks go to D. Wang and S. Chen, the chief scientists of these cruises, and H. Mao for providing CTD data. Thanks to Y. K. Tam for her assistance with general technical support.

\section{LITERATURE CITED}

Agustí S, Llabrés M (2007) Solar radiation-induced mortality of marine pico-phytoplankton in the oligotrophic ocean. Photochem Photobiol 83:793-801

Bertoni R, Jeffrey WH, Pujo-Pay M, Oriol L, Conan P, Joux F (2011) Influence of water mixing on the inhibitory effect of UV radiation on primary and bacterial production in Mediterranean coastal water. Aquat Sci 73:377-387

Bothwell ML, Sherbot DMJ, Pollock CM (1994) Ecosystem response to solar ultraviolet-B radiation: influence of trophic-level interactions. Science 265:97-100

- Bratbak G, Heldal M, Norland S, Thingstad TF (1990) Viruses as partners in spring bloom microbial trophodynamics. Appl Environ Microbiol 56:1400-1405

Brussaard CPD (2004) Optimization of procedures for counting viruses by flow cytometry. Appl Environ Microbiol 70:1506-1513

Buma AGJ, Helbling EW, Karin de Boer M, Villafañe VE (2001) Patterns of DNA damage and photoinhibition in temperate South-Atlantic picophytoplankton exposed to solar ultraviolet radiation. J Photochem Photobiol B 62: 9-18

Carlson CA, Ducklow HW, Michaels AF (1994) Annual flux of dissolved organic carbon from the euphotic zone in the northwestern Sargasso Sea. Nature 371:405-408

Carrillo P, Medina-Sánchez JM, Villar-Argaiz M (2002) The interaction of phytoplankton and bacteria in a high mountain lake: importance of the spectral composition of solar radiation. Limnol Oceanogr 47:1294-1306

- Carrillo P, Delgado-Molina JA, Medina-Sánchez JM, Bullejos FJ, Villar-Argaiz M (2008) Phosphorus inputs unmask negative effects of ultraviolet radiation on algae in a high mountain lake. Glob Change Biol 14:423-439

Chen CTA (2010) Cross-boundary exchanges of carbon and nitrogen in continental margins. In: Liu KK, Atkinson L, Quiñones R, Talaue-McManus L (eds) Carbon and nutrient fluxes in continental margins: a global synthesis. IGBP Book Series. Springer, Berlin, p 561-574

> Chen B, Liu H, Landry MR, Dai M, Huang B, Sun J (2009) Close coupling between phytoplankton growth and microzooplankton grazing in the western South China Sea. Limnol Oceanogr 54:1084-1097

Conan P, Turley C, Stutt E, Pujo-Pay M, Van Wambeke F (1999) Relationship between phytoplankton efficiency and the proportion of bacterial production to primary production in the Mediterranean Sea. Aquat Microb Ecol 17:131-144

> Conan P, Joux F, Torréton JP, Pujo-Pay M, Douki T, Rochelle-Newall E, Mari X (2008) Effect of solar ultraviolet radiation on bacterio- and phytoplankton activity in a large coral reef lagoon (southwest New Caledonia). Aquat Microb Ecol 52:83-98

Cullen JJ, Lesser MP (1991) Inhibition of photosynthesis by ultraviolet radiation as a function of dose and dosage rate: results for a marine diatom. Mar Biol 111:183-190

Culley AI, Welschmeyer NA (2002) The abundance, distribution, and correlation of viruses, phytoplankton, and prokaryotes along a Pacific Ocean transect. Limnol Oceanogr 47:1508-1513

Dortch Q, Packard TT (1989) Differences in biomass structure between oligotrophic and eutrophic marine ecosystem. Deep-Sea Res A 36:223-240

> Doyle SA, Saros JE, Williamson CE (2005) Interactive effects of temperature and nutrient limitation on the response of alpine phytoplankton growth to ultraviolet radiation. Limnol Oceanogr 50:1362-1367

- Estevez MS, Malanga G, Puntarulo S (2001) UV-B effects on Antarctic Chlorella sp. cells. J Photochem Photobiol B 62: 19-25

Fuhrman JA (1999) Marine viruses and their biogeochemical and ecological effects. Nature 399:541-548

> Fuhrman JA, Noble RT (1995) Viruses and protists cause similar bacterial mortality in coastal seawater. Limnol Oceanogr 40:1236-1242

Fukuda R, Ogawa H, Nagata T and Koiki I (1998) Direct determination of carbon and nitrogen contents of natural bacterial assemblages in marine environments. Appl Environ Microbiol 64:3352-3358

> Gao K, Li G, Helbling EW, Villafañe VE (2007) Variability of UVR effects on photosynthesis of summer phytoplankton assemblages from a tropical coastal area of the South China Sea. Photochem Photobiol 83:802-809

Garcia-Pichel F (1994) A model for internal shelf-shading in planktonic organisms and its implications for the usefulness of ultraviolet sunscreens. Limnol Oceanogr 39: 1704-1717

> Häder DP, Helbling EW, Williamson CE, Worrest RC (2011) Effects of UV radiation on aquatic ecosystems and interactions with climate change. Photochem Photobiol Sci 10:242-260

Hamre B, Stamnes JJ, Frette O, Erga SR, Stamnes K (2008) Could stratospheric ozone depletion lead to enhanced aquatic primary production in the polar regions? Limnol Oceanogr 53:332-338

> He L, Yin K, Yuan X, Li D, Zhang D, Harrison PJ (2009) Spatial distribution of viruses, bacteria and chlorophyll in the northern South China Sea. Aquat Microb Ecol 54: 153-162

Helbling EW, Gao KS, Gonçalves RJ, Wu HY, Villafañe VE (2003) Utilization of solar UV radiation by coastal phytoplankton assemblages off SE China when exposed to fast mixing. Mar Ecol Prog Ser 259:59-66

> Hernández KL, Quiñones RA, Daneri G, Helbling EW (2006) Effects of solar radiation on bacterioplankton production in the upwelling system off central-southern Chile. Mar Ecol Prog Ser 315:19-31

> Hoch MP, Kirchman DL (1993) Seasonal and inter-annual variability in bacterial production and biomass in a temperate estuary. Mar Ecol Prog Ser 98:283-295 
Jeffrey WH, Aas P, Lyons MM, Coffin RB, Pledger RJ, Mitchell DL (1996) Ambient solar radiation-induced photodamage in marine bacterioplankton. Photochem Photobiol 64:419-427

Jeffrey WH, Kase JP, Wilhelm SW (2000) Ultraviolet radiation effects on heterotrophic bacterioplankton and viruses in marine ecosystems. In: de Mora S, Demers S, Vernet $M$ (eds) The effects of UV radiation in the marine environment. Cambridge University Press, Cambridge, p 206-236

Joux F, Jeffrey WH, Lebaron P, Mitchell DL (1999) Marine bacterial isolates display diverse responses to UV-B radiation. Appl Environ Microbiol 65:3820-3827

Joux F, Jeffrey WH, Abboudi M, Neveux J, Pujo-Pay M, Oriol L, Naudin JJ (2009) Ultraviolet radiation in the Rhône river lenses of low salinity and in marine waters of the northwestern Mediterranean Sea: attenuation and effects on bacterial activities and net community production. Photochem Photobiol 85:783-793

Kirk JTO (1994) Characteristics of the light field in highly turbid waters: a Monte-Carlo study. Limnol Oceanogr 39: 702-706

Knap A, Michaels A, Close A, Ducklow H, Dickson A (1994) Protocols for the Joint Global Ocean Flux Study (JGOFS) core measurements, IOC manual and guides 29. Scientific Committee on Ocean Research, UNESCO, Paris, p 11-122

> Lindell MJ, Granéli W, Tranvik LJ (1995) Enhanced bacterial growth in response to photochemical transformation of dissolved organic matter. Limnol Oceanogr 40: 195-199

Llabrés M, Agustí S (2006) Picophytoplankton cell death induced by UV radiation: evidence for oceanic Atlantic communities. Limnol Oceanogr 51:21-29

Madronich S (1993) The atmosphere and UVB radiation at ground level. In: Björn LO, Moan J, Nultsch W, Young AR (eds) Environmental UV photobiology. Plenum Press, New York, NY, p 1-39

Medina-Sánchez JM, Villar-Argaiz M, Carillo P (2002) Modulation of the bacterial response to spectral solar radiation by algae and limiting nutrients. Freshw Biol 47: 2191-2204

> Medina-Sánchez JM, Villar-Argaiz M, Carrillo P (2006) Solar radiation-nutrient interaction enhances the resource and predation algal control on bacterioplankton: a short-term experimental study. Limnol Oceanogr 51:913-924

> Middelboe M, Lyck PG (2002) Regeneration of dissolved organic matter by viral lysis in marine microbial communities. Aquat Microb Ecol 27:187-194

> Müller-Niklas G, Heissenberger A, Puskaríc S, Herndl GJ (1995) Ultraviolet-B radiation and bacterial metabolism in coastal waters. Aquat Microb Ecol 9:111-116

Noble RT, Fuhrman JA (1997) Virus decay and its causes in coastal waters. Appl Environ Microbiol 63:77-83

> Obernosterer I, Reitner B, Herndl GJ (1999) Contrasting effects of solar radiation on dissolved organic matter and its bioavailability to marine bacterioplankton. Limnol Oceanogr 44:1645-1654

> Ogbebo FE, Ochs C (2008) Bacterioplankton and phytoplankton production rates compared at different levels of solar ultraviolet radiation and limiting nutrient ratios. J Plankton Res 30:1271-1284

Plante AJ, Arts MT (2000) Effects of chronic, low levels of UV radiation on carbon allocation in Cryptomonas erosa and competition between C. erosa and bacteria in continuous cultures. J Plankton Res 22:1277-1298

Porter KG, Feig YS (1980) The use of DAPI for identifying and counting aquatic microflora. Limnol Oceanogr 25: 943-948

Simon M, Azam F (1989) Protein content and protein synthesis rates of planktonic marine bacteria. Mar Ecol Prog Ser 51:201-213

Suttle CA (2005) Viruses in the sea. Nature 437:356-361

Suttle CA (2007) Marine viruses-major players in the global ecosystem. Nat Rev Microbiol 5:801-812

> Vaughan PP, Bullock A, Joux F, Jeffrey WH (2010) The effects of solar radiation on the stability of ${ }^{3} \mathrm{H}$-thymidine and ${ }^{3} \mathrm{H}$-leucine during bacterioplankton production measurements. Limnol Oceanogr Methods 8:562-566

Vidussi F, Mostajir B, Fouilland E, Le Floc'h E and others (2011) Effects of experimental warming and increased ultraviolet $\mathrm{B}$ radiation on the Mediterranean plankton food web. Limnol Oceanogr 56:206-218

> Wang G, Cao W, Yang Y, Zhou W, Liu S, Yang D (2010) Variations in light absorption properties during a phytoplankton bloom in the Pearl River estuary. Cont Shelf Res 30:1085-1094

Weinbauer MG, Wilhelm SW, Suttle CA, Garza DR (1997) Photoreactivation compensates for UV damage and restores infectivity to natural marine virus communities. Appl Environ Microbiol 63:2200-2205

Wilhelm SW, Weinbauer MG, Suttle CA, Jeffrey WH (1998) The role of sunlight in the removal and repair of viruses in the sea. Limnol Oceanogr 43:586-592

Wilhelm SW, Brigden SM, Suttle CA (2002) A dilution technique for the direct measurement of viral production: a comparison in stratified and tidally mixed coastal waters. Microb Ecol 43:168-173

Winter C, Moeseneder MM, Herndl GJ (2001) Impact of UV radiation on bacterioplankton community composition. Appl Environ Microbiol 67:665-672

- Wommack KE, Colwell RR (2000) Virioplankton: viruses in aquatic ecosystems. Microbiol Mol Biol Rev 64:69-114

> Xenopoulos MA, Frost PC, Elser JJ (2002) Joint effects of UV radiation and phosphorus supply on algal growth rate and elemental composition. Ecology 83:423-435

> Yin K, Qian PY, Wu MCS, Chen JC, Huang L, Song X, Jian W (2001) Shift from P to N limitation of phytoplankton growth across the Pearl River estuarine plume during summer. Mar Ecol Prog Ser 221:17-28

- Yuan X, Yin K, Harrison PJ, Cai WJ, He L, Xu J (2010) Bacterial production and respiration in subtropical Hong Kong waters: influence of the Pearl River discharge and sewage effluent. Aquat Microb Ecol 58:167-179

Yuan XC, Yin K, Cai WJ, Ho AY, Xu J, Harrison PJ (2011a) Influence of seasonal monsoons on net community production and $\mathrm{CO}_{2}$ in subtropical Hong Kong coastal waters. Biogeosciences 8:289-300

Yuan X, Yin K, Harrison PJ, He L, Xu J (2011b) Variations in apparent oxygen utilization and effects of $\mathrm{P}$ addition on bacterial respiration in subtropical Hong Kong waters. Estuar Coast 34:536-543

Yuan X, He L, Yin K, Pan G, Harrison PJ (2011c) Bacterial distribution and nutrient limitation in relation to different water masses in the coastal and northwestern South China Sea in late summer. Cont Shelf Res 31:1214-1223

> Ziegler S, Benner R (2000) Effects of solar radiation on dissolved organic matter cycling in a subtropical seagrass meadow. Limnol Oceanogr 45:257-266 